\title{
KERJA SAMA SEKOLAH DENGAN KOMUNITAS LITERASI DALAM PENINGKATAN LITERASI UNTUK ORANG TUA DI MASA PANDEMI COVID-19
}

\author{
Oleh : Sri Rahayu' dan Heru Kurniawan² \\ MI Al Falah UM Jakarta Timur ${ }^{1}$, Institut Agama Islam Negeri Purwokerto² \\ (cararici@gmail.com¹ dan heru_1982@gmail.com²)
}

\begin{abstract}
Abstrak: Di masa Pandemi Covid-19 ini telah mengkondisikan anak-anak untuk banyak belajar dengan orang tua, karena kegiatan belajar di sekolah dilakukan dengan model pembelajaran jarak jauh. Keadaan ini menimbulkan banyak persoalan bagi orang tua dan sekolah, salah satunya adalah persoalan komunikasi. Literasi dipandang sebagai sarana yang dapat digunakan untuk memperoleh dan mengkomunikasikan informasi. Di sinilah, program kerja sama yang dilakukan Komunitas Literasi Wadas Kelir Purwokerto dengan MI Al Falah UM Jakarta Timur menjadi solusi penting dalam mengatasi persoalan yang dihadapi. Penelitian ini bertujuan untuk mengeksplorasi kegiatan literasi orang tua selama mendampingi belajar anak di rumah. Metode penelitian yang digunakan adalah deskripsi kualitatif sebagai cara mengeksplorasi model kegiatan literasi orang tua yang dikembangkan dalam empat kegiatan literasi menulis yang menarik, yaitu (1) Performative, pengkondisikan kegiatan membaca dan menulis menggunakan bahasa yang dilakukan oleh orang tua; (2) Functional, mengkondisikan orang tua untuk terbiasa menggunakan bahasa tulis untuk mengekspresikan kegiatan sehari-harinya; (3) Informational, memberikan keterampilan pada orang tua untuk bisa mengangkes pengetahuan dari berbagai sumber dengan bahasa dan memberikan teknik-teknik cara membaca yang baik agar memahami benar konsep ilmu pengetahuan yang disajikan; (4) Epistemic, memberikan keterampilan dalam mentransformasi pengetahuan dalam tulisan sehingga orang tua bisa menulis dengan baik. Teknik pengumpulan data yang digunakan adalah wawancara terprogram terhadap orang tua dan dokumentasi berupa tulisan, foto, dan video. Hasil penelitian menunjukkan literasi orang tua mengalami peningkatan setelah melalui pendampingan kegiatan literasi pihak sekolah dan Komunitas Literasi Wadas Kelir. Hal ini dibuktikan dengan orang tua mampu menuliskan pengalamannya selama mendampingi belajar anak dan hasilnya dibukukan.
\end{abstract}

Kata-kata kunci: kerja sama sekolah, komunitas literasi, literasi orang tua.

\section{SCHOOL COLLABORATION WITH LITERACY COMMUNITY IN INCREASING LITERACY OF PARENTS DURING COVID-19 PANDEMIC}

Abstract: During the Covid-19 Pandemic, children had a lot to learn from their parents because learning activities at school were carried out using a distance learning model. This situation creates many problems for parents, one of the problem is communication.Literacy could be used to obtain and communicate information. Accordongly, collaboration program between Literacy Community Wadas Kelir Purwokerto and MI Al-Falah UM East Jakarta is an important solution in overcoming problem. This study aims to explore literacy activity of parents 
while accompanying children during online learning. The research method used is qualitative description as a way to exploring literacy of parents that developed in four interesting writing literacy activities, (1) Performative, carried out through conditioning reading and writing activities using language by parents; (2) Functional, conditioning parents to accustomed use written language to express their daily activity; (3) Informational, give skill for parents to access the knowledge from various sources with language provide good reading technique in order to understand the scientific concept properly; (4) Epistemic, provide skill in transforming knowledge in writing so that parents can write well. Technique of data collection are programmed interview with parents and documentation such as writing document, photo, and video. The result showed that literacy of parents has increased after assisting the literacy activity of school and Wadas Kelir Literacy Community. This is evidenced by the pulication of book containing experience of parents while accompanying children during online learning.

Keywords: school collaboration, literacy community, literacy of parents.

\section{PENDAHULUAN}

Pandemi Covid-19 mengharuskan masyarakat melakukan pembatasan aktivitas sosial, hal ini tidak terkecuali aktivitas pendidikan masyarakat. Pada 4 Maret 2020, UNESCO (United Nation Educational Scientific and Cultural Organization) menyarankan penggunaan pembelajaran jarak jauh dengan membuka platform pendidikan yang dapat digunakan sekolah dan guru untuk menjangkau peserta didik dari jarak jauh dalam mengatasi gangguan pendidikan. Sejalan dengan hal itu, Kementerian Pendidikan dan Kebudayaan Republik Indonesia mengeluarkan Surat Edaran No. 36962/MPK.A/HK/2020 tentang pembelajaran secara daring dan bekerja dari rumah dalam rangka pencegahan penyebaran Corona Virus Disease (Covid-19) (Kemdikbud, 2020). Kebijakan pembelajaran daring mengharuskan guru dan siswa melakukan pembelajaran jarak jauh. Pembelajaran Jarak Jauh (PJJ) adalah ketika dalam proses pembelajaran tidak terjadi kontak dalam bentuk tatap muka langsung antara pengajar dan pembelajar. Proses pembelajaran dilaksanakan dengan menggunakan media seperti komputer, televisi, radio, internet, video, dan sebagainya sebagai alat komunikasi (Munir, 2009).
Selama Pembelajaran Jarak Jauh (PJJ) peran guru dan tutor akan semakin minimal. WHO (World Health Organization) (2020) menyebutkan bahwa peran orang tua selama pembelajaran jarak jauh menjadi sangat sentral. Di sini dapat diidentifikasi setidaknya ada empat peran orang tua selama pembelajaran jauh berlangsung, yaitu orang tua sebagai guru, di mana orang tua membimbing proses belajar anak; orang tua sebagai fasilitator, sebagai sarana dan prasarana pembelajaran; orang tua sebagai motivator, pemberi semangat untuk belajar serta memperoleh prestasi yang baik; orang tua sebagai pengaruh atau director (Azmi, 2020). Sebenarnya peran orang tua dalam pembelajaran anak bukanlah hal baru, karena peran orang tua adalah kegiatan berkelanjutan.

Namun, kenyataan yang tidak bisa dihindari, selama ini peran orang tua dalam pengasuhan dan perawatan lebih menonjol, sementara pendidikan akademik seringkali dialihtugaskan pada pihak kedua, yaitu sekolah. Orang tua juga sering kurang menganggap bahwa komunitas literasi sebagai salah satu penyelenggara pendidikan nonformal bisa berperan penting dalam penyelenggarakan pendidikan untuk anak-anak di masyarakat. 
Pembelajaran Jarak Jauh (PJJ) terasa sulit dijalankan. Apalagi saat ini orang tua dituntut untuk mampu berperan sebagai pengganti guru, mereka harus belajar kembali materi pelajaran yang sedang dipelajari anak saat itu. Bagi orang tua dengan latar pendidikan kurang memadai, tentu hal ini sangat tidak mudah (Simanjuntak, 2020). Tidak hanya itu, orang tua juga harus bisa memfasilitasi sarana dan prasarana pembelajaran daring agar pembelajaran bisa berjalan lancar. Orang tua pun harus siap sedia dan bersabar mendampingi anak-anak belajar di rumah. Beratnya mendampingi anak selama belajar di rumah membuat orang tua bereaksi. Sebagian bahkan melapor kepada Komisi Perlindungan Anak Indonesia (KPAI) karena anak serta orang tua mengalami stres dan menilai pembelajaran daring tidak efektif. Menanggapi permasalahan terkait tidak optimalnya pembelajaran jarak jauh, Menteri Pendidikan dan Kebudayaan, Nadiem Makarim mengakui tidak mempunyai opsi lain mengingat kasus positif Covid-19 terus meningkat (Sindonews, 2020).

Lalu bagaimana persoalan pembelajaran daring dapat terselesaikan sementara pembelajaran tatap muka belum memungkinkan untuk dilaksanakan?

Hasil penelitian yang dilakukan oleh Tsaniya Zahra Yuthika Wardhani dan Hetty Krisnani yang berjudul "Optimalisasi Peran Pengawasan Orang Tua Dalam Pelaksanaan Sekolah Online Di Masa Pandemi Covid-19" pada bulan April tahun 2020 menyatakan bahwa komunikasi antara orang tua dan pihak sekolah (guru) menjadi kunci penting agar PJJ berjalan dengan baik. Peran orang tua sebagai roda kemudi pembelajaran harus dapat memberikan bimbingan dan informasi yang tepat sepanjang proses perjalanan pembelajaran. Namun, penelitian ini masih menitikberatkan pada kendala dan dampak PJJ bagi guru dan anak, serta alternatif cara yang dapat dilakukan orang tua sebagai upaya mendampingi anak selama pembelajaran daring.
Penelitian tersebut belum memberikan solusi terhadap peningkatan komunikasi orang tua dan guru yang selama ini masih menemui banyak kendala (Wardhani \& Krisnani, 2020).

Penelitian ini dapat menyempurnakan penelitian tersebut, yakni dalam upaya meningkatkan komunikasi antara orang tua dan sekolah melalui peningkatkan literasi orang tua. Penelitian ini fokus mengeksplorasi kegiatan literasi orang tua melalui kerja sama sekolah dan komunitas literasi selama orang tua mendampingi anak belajar di rumah(Padmadewi, Artini, Nitiasih, \& Suandana, 2018). Sesuai dengan pendapat (Rahman, Sopandi, Widya, \& Yugafiati, 2017) bahwa literasi merupakan sarana yang digunakan untuk memperoleh dan mengkomunikasikan suatu informasi. Persoalan komunikasi antara orang tua dan pihak sekolah dapat dihilangkan dengan memberdayakan peran aktif komunitas literasi dalam penyelenggaraan pendidikan masyarakat.

Disinilah diperlukan adanya sinergi antara orang tua, sekolah, dan komunitas literasi yang ada di masyarakat, agar pembelajaran bisa berjalan sebagaimana mestinya meski proses pembelajaran dilaksanakan secara daring/jarak jauh. Mattewakkang berpendapat bahwa harus ada perubahan orientasi pendampingan orang tua, guru sebaiknya tidak berfokus pada capaian akademik/ kognitif saja, tetapi juga pada pendidikan yang bermakna (Kurniati, Nur Alfaeni, \& Andriani, 2020). Guru harus merancang pelaksanaan pembelajaran di rumah sesuai dengan kondisi pandemi Covid-19, yang dapat memberikan dorongan, motivasi, dan apresiasi kepada siswa maupun orang tua. Orang tua harus dilibatkan dalam kegiatan yang membuatnya bersemangat, berdaya, cerdas, aktif, dan kreatif, dan tentu saja peran komunitas literasi juga sangat penting dalam mengubah paradigma ini(Suranny, Kidul, \& Ngadirojo, 2018). Hal ini terjadi karena saat 
sekolah tidak bisa hadir secara langsung, maka pendekatan komunitas literasi yang dilakukan secara langsung maupun tidak, bisa menjadi solusi tersendiri untuk mengatasi persoalan ini.

UNICEF (United Nations Children's Fund) (2020) pun mengungkapkan bahwa terdapat beberapa cara agar orang tua dapat membantu pengasuhan anak di masa pandemi, salah satunya dengan menciptakan waktu bersama dengan anak yang berkualitas. Guru sebagai fasilitator merancang pembelajaran yang melibatkan orang tua, anak, dan lingkungan (komuitas literasi) diantaranya; beribadah bersama; memasak bersama; olah raga bersama; mengerjakan pekerjaan rumah bersama; membuat proyek bersama; membaca buku bersama; bermain gawai bersama. Setelah melakukan berbagai kegiatan bersama, yang melibatkan guru dan komunitas literasi yang memfasilitasi orang tua untuk menuliskan pengalamannya selama mendampingi anak belajar di rumah dalam sebuah jurnal harian. Kegiatan menulis sendiri memiliki banyak manfaat. Penelitian dalam Journal of Health and Psychology menyatakan bahwa menulis dapat mengurangi kadar stres, menurunkan tekanan darah serta meningkatkan fungsi hati. Menurut Dr. James Pannebakker dalam bukunya yang berjudul Writing to Heal, menjelaskan bahwa menulis memiliki komponen penyembuhan yang baik. Dengan menulis tentang pengalaman traumatis dan emosional, manusia akan mengatur, menerima, dan melepas pikiran negatif setiap hari (Indopositive, 2016). Tentu kegiatan menulis bisa menjadi alternatif cara mengurangi beban stress orang tua dalam mendampingi anak selama PJJ.

Tidak hanya berdampak positif terhadap kesehatan mental, kegiatan menulis orang tua diharapkan dapat meningkatkan kecakapan literasi orang tua. Literasi yang oleh Teale dan Sulzby dalam (Padmadewi et al., 2018) diartikan sebagai melek huruf, kemampuan baca tulis, kecakapan dalam menulis. Menurut Edward(Pancarrani, Amroh, \& Noorfitriana, 2017), meningkatnya proses pendidikan di rumah dipengaruhi tingkat literasi orang tua. Disadari atau tidak, literasi berpengaruh pada perkembangan bahasa. Perkembangan bahasa merupakan jalan utama dari pendidikan literasi dan penting untuk kebutuhan komunikasi (Pancarrani et al., 2017).

Dari sinilah, saat sekolah memiliki program kegiatan pendampingan literasi bagi orang tua, maka idealnya harus melibatkan komunitas literasi. Dengan komunitas literasi inilah, maka kegiatan literasi sekolah untuk orang tua dapat dirancang oleh guru selama proses pembelajaran jarak jauh di masa pandemi Covid-19 yang dapat meningkatkan kecakapan literasi orang tua (Cahyati \& Kusumah, 2020). Hal ini penting karena keterampilan komunikasi tidak lepas dari peran literasi. Sebagai bentuk apresiasi terhadap perjuangan orang tua dalam perannya menggantikan guru sebagai pembimbing di rumah, tulisan-tulisan orang tua disatukan untuk kemudian dibukukan. Apresiasi ini sebagai upaya untuk meningkatkan semangat dan kepercayaan diri orang tua selama mendapingi anak belajar di rumah. Sejalan dengan pendapat Kaburise (Rahman et al., 2017) yang menyatakan bahwa apresiasi dapat meningkatkan motivasi untuk terus mingkatkan keterampilan komunikasi. Disinilah penelitian ini dimaksudkan untuk mengeksplorasi dan mengetahui sejauh mana pendampingan kegiatan literasi orang tua melalui kerja sama MI Al Falah UM dan Komunitas Literasi Wadas Kelir dapat meningkatkan literasi orang tua. Dengan meningkatknya kecakapan literasi orang tua diharapkan dapat menciptakan sinergi yang positif dalam bentuk komunikasi efektif antara pihak sekolah dan keluarga, serta kegiatan mendampingi anak belajar di rumah berdampak positif bagi orang tua yang memiliki peran sentral selama masa pandemi Covid-19. 


\section{METODE PENELITIAN}

Metode penelitian yang digunakan adalah deskripsi kualitatif yang memfokuskan pada kegiatan literasi orang tua di masa pandemi Covid-19, yang dilakukan oleh Komunitas Literasi Wadas Kelir Purwokerto bekerja sama dengan MI Al-Falah UM Jakarta Timur dan dilakukan secara daring. Metode kualitatif oleh Cresswell didefinisikan sebagai suatu pendekatan untuk mengeksplorasi dan memahami suatu gejala sentral di mana informasi yang didapat kemudian dianalisis berupa deskripsi (Raco, 2010). Deskripsi tidak dimaksudkan untuk mencari kebenaran atau fakta, tetapi untuk menggambarkan kembali kejadian dengan teliti (Subandi, 2011).

Teknik pengumpulan data yang digunakan adalah wawancara mendalam dan dokumentasi. Wawancara mendalam bertujuan untuk menggali data yang diperlukan. Peneliti menyiapkan sejumlah pertanyaan terhadap responden terkait pesepsi, pendapat, pengalaman, perasaan, kemampuan menulis dan proses kreatif menulis. Responden yang diwawancarai adalah orang tua wali murid yang melakukan kegiatan literasi melalui pendampingan sekolah MI Al Falah UM dan Komunitas Literasi Wadas Kelir. Dokumen yang digunakan berupa foto, video, dan tulisan yang memberikan gambaran proses kegiatan literasi yang dijalani orang tua selama mendampingi proses belajar anak di masa pandemi Covid-19. Analisis dokumentasi dari berbagai sumber berupa foto, video maupun tulisan dikelola untuk membantu menampilkan kembali data-data yang belum diperoleh serta mengecek kebenaran agar lebih memudahkan deskripsi.

Pada penelitian ini, teknik analisis yang digunakan adalah analisis interaktif di mana terdapat tiga komponen yang terdiri dari; (1) reduksi data, membuat fokus dan penyederhanaan data yang relevan terhadap penelitian; (2) sajian data, menyusun dan menyajikan data agar dapat dimengerti dan dipahami; (3) penarikan kesimpulan, analisis mendalam terhadap data untuk kemudian disimpulkan dan mengkontruksinya menjadi bangunan pengetahuan.

\section{HASIL DAN PEMBAHASAN}

Penelitian ini fokus mengeksplorasi dan mengetahui sejauh mana pendampingan kegiatan literasi orang tua melalui kerja sama MI Al Falah UM dan Komunitas Literasi Wadas Kelir dapat meningkatkan literasi orang tua di masa pandemi Covid-19.

Kegiatan literasi berangkat pada pembelajaran jarak jauh yang dilakukan sekolah selama pandemi Covid-19 dilaksanakan di bawah bimbingan orang tua. Dari sinilah, sekolah MI Al Falah UM Jakarta Timur kemudian menjalin kemitraan program dengan Komunitas Literasi Wadas Kelir Purwokerto untuk meningkatkan literasi orang tua selama PJJ. Peran Komunitas Literasi Wadas Kelir dilakukan dari aspek: pemberian materi, konsultasi, penugasan menulis, edit dan revisi, serta penerbitannya yang dilakukan secara online. Sedangkan sekolah, melalui gurugurunya bertindak langsung sebagai fasilitator dan motivator dalam menciptakan iklim belajar orang tua dalam menulis selama pandemi Covid-19.

Kegiatan literasi menulis yang dilakukan oleh orang tua dikembangkan dengan model berpola yang disesuaikan dengan tingkatan literasi menurut Wells sebagai berikut; (1) performative, kegiatan membaca dan menulis menggunakan bahasa; (2) functional, menggunakan bahasa untuk memenuhi kebutuhan sehari-hari; (3) informational, mengangkes pengetahuan dari berbagai sumber dengan bahasa; (4) epistemic, mentransformasi pengetahuan dalam bahasa (Pancarrani et al., 2017). 


\section{Performative}

Orangyang memiliki tingkat literasi performatif ditandai dengan mampu membaca dan menulis serta berbicara dengan simbol-simbol yang digunakan (bahasa). Tingkat ini adalah tingkat paling rendah kemampuan literasi. Kegiatan orang tua dalam mendampingi proses pembelajaran jarak jauh yang dapat mengasah kecakapan literasi tingkatan ini adalah Komunitas Literasi Wadas Kelir memberikan referensi dan panduan pembacaan yang efektif. Kemudian guru MI Al Falah UM Jakarta Timur memberikan instruksi tertulis melalui pesan WhatsApp berisi kegiatan pembelajaran hari itu. Pada awal masa PJJ, lebih dari $80 \%$ orang tua kesulitan memahami instruksi guru. Orang tua berbondong-bondong mengajukan pertanyaan. Pertanyaan yang paling banyak diajukan diantaranya; (1) Apa yang harus dilakukan? (2) Di mana tugas tersebut dikerjakan? (3) Mengkonfirmasi ulang tugas yang diberikan karena takut salah mengerjakan. Dengan koordinasi antara Komunitas Literasi Wadas Kelir dan guru MI Al Falah UM Jakarta Timur persoalan itu dapat diatasi satu persatu melalui jawaban yang disampikan dalam group WhatsApp.

Hasilnya, pada minggu pertama PJJ terlihat orang tua yang awalnya mengalami kesulitan mendampingi belajar anak karena kesulitan memahami instruksi terutama instruksi tertulis (dalam bentuk bacaan) perlahan mulai diatasi. Seringkali orang tua mengajukan pertanyaan bahkan pada hal-hal yang remeh temeh, dan semuanya diatasi dengan baik. Guru juga mengalami kesulitan memahami pertanyaan orang tua melalui pesan tertulis karena susunan kalimat yang berantakan, tapi dengan bimbingan Komunitas Literasi Wadas Kelir semua diatasi dengan baik.

Di minggu pertama, Komunitas Literasi Wadas Kelir dan guru MI Al Falah UM Jakarta
Timur harus menyampaikan instruksi melalui pesan tertulis secara rinci dan pesan suara untuk mengurangi kesulitan orang tua. Pada minggu berikutnya, Komunitas Literasi Wadas Kelir dan guru MI Al Falah UM Jakarta Timur mengurangi pemberian instruksi melalui pesan suara, orang tua mulai terbiasa dengan instruksi dalam bentuk bacaan. Mereka mengakui pada awalnya harus mengulang-ngulang membaca instruksi agar dapat memahami informasi dan menyelesaikan pembelajaran dengan baik, tetapi semakin lama mereka mulai terbiasa dan semakin mudah dalam memahami instruksi. Mereka juga percaya diri dengan pesan yang mereka terima tanpa harus mengkonfirmasi ulang pada guru. Jumlah pertanyaan yang diajukan tiap harinya semakin berkurang. Pertanyaan yang diajukan lebih kepada materi pelajaran. Hal ini menunjukkan bahwa orang tua siswa telah mencapai tingkatan performatif kemampuan literasi.

\section{Functional}

Tingkatan kedua dalam kemampuan literasi adalah functional. Pada tingkatan ini diharapkan seseorang dapat menggunakan bahasa untuk memenuhi kehidupan seharihari, seperti membaca buku manual (Wells, 2008). Dalam mengasah kemampuan literasi tingkatan ini, Komunitas Literasi Wadas Kelir dan guru MI Al Falah UM Jakarta Timur membaginya dalam dua kegiatan, yaitu; (1) meningkatkan kemampuan literasi media pada orang tua; (2) mengasah penggunaan bahasa untuk membuat menu masakan.

Pembelajaran jarak jauh membutuhkan media sebagai alat komunikasi utama dalam kegiatan belajar mengajar. Untuk itu, literasi media pada orang tua dianggap sesuatu yang mendesak dan harus dimiliki karena kebutuhan penggunaan media telah menjadi kebutuhan sehari-hari. Menurut UNESCO (2014), literasi media adalah seperangkat keterampilan, sikap, 
dan pengetahuan yang diperlukan untuk memahami dan memanfaatkan berbagai jenis media di mana informasi dikomunikasikan dari pengirim ke penerima seperti gambar, suara, dan video. Orang tua sebagai pengganti guru di rumah harus membimbing anak-anaknya dalam kegiatan pembelajaran. Pada PJJ yang membutuhkan tatap muka daring, guru memanfaatkan media komunikasi seperti zoom meeting, google meet atau video call WhatsApp.

Sedangkan untuk proses pembelajaran yang tidak membutuhkan tatap muka, guru memanfaatkan google classroom, email ataupun Whats $A p p$ untuk mengirimkan foto, video maupun dokumen dalam bentuk power point, word maupun pdf. Pada awal PJJ, tanggal 16 Maret 2020, guru memberikan panduan (manual) secara tertulis dan video tutorial melalui grup WhatsApp yang berisi cara mengunduh sampai tata cara penggunaan aplikasi-aplikasi yang dibutuhkan selama PJJ secara bertahap. Minggu pertama aplikasi zoom meeting dan google classroom, minggu kedua aplikasi google meet dan google classroom. Proses pembelajaran tatap muka daring diawal PJJ, sering kali terhambat karena orang tua kesulitan mengoperasikan aplikasi tersebut. Proses pembelajaran tatap muka daring harus tertunda dari waktu yang telah ditentukan. Pada aplikasi google classroom, orang tua merasa lebih sulit karena banyak fitur di dalamnya. Oleh karenanya, guru memberikan waktu selama 2 minggu bagi orang tua untuk mempelajarinya. Hal yang sering terjadi dalam penggunaan google classroom adalah kesalahan dalam mengunggah dokumen, siswa mengunggah dokumen bukan pada bagian yang seharusnya. Mereka lebih banyak mengunggahnya di bagian komentar bukan dibagian tugas. Selama orang tua dan siswa belum bisa mengoperasikan aplikasi tesebut, dokumen dikirim melalui pesan WhatsApp.

Dari hasil wawancara, kebanyakan dari orang tua mengabaikan panduan, mereka lebih memilih untuk mencoba-coba lalu langsung bertanya jika menemui kebuntuan. Banyak orang tua yang mengeluh dan meminta agar setiap tugas dikirim melalui pesan WhatsApp saja. Menurutnya, WhatsApp lebih mudah dan sederhana. Namun, guru terus memberi dorongan dan semangat pada orang tua dan siswa agar bisa "menaklukkan" teknologi dengan mau mempelajari panduan dan terus diberikan bimbingan oleh guru. Mereka mengakui bahwa kesulitan yang mereka temui akibat kurang seksama mempelajari panduan. Setelah dua minggu, seluruh orang tua dan siswa sudah bisa mengoperasikan aplikasi-aplikasi yang digunakan selama proses pembelajaran jarak jauh berlangsung.

Ada kepuasan tersendiri setelah mereka berhasil "menaklukkan" dan bisa mengoperasikan aplikasi. Orang tua bahkan mengakui bahwa google classroom lebih memudahkan mereka dalam melakukan proses pembelajaran karena lebih teroganisir. Selain itu, anak-anak lebih bersemangat belajar karena berhasil menggunakan beberapa aplikasi dalam proses pembelajaran. Bahkan mereka telah siap belajar sejak sholat subuh untuk pembelajaran tatap muka daring yang dimulai pukul 06.30WIB. Untuk mengerjakan dokumen dalam bentuk pdf, power point maupun word siswa tidak mengalami kesulitan karena sudah dipelajari di sekolah pada mata pelatajaran Teknologi Informasi dan Komputer (TIK).

Kegiatan kedua, yaitu mengasah penggunaan bahasa dalam pemenuhan kebutuhan. Orang tua dan siswa bekerja sama untuk menyelesaikan masakan berdasarkan resep yang dikirimkan secara tertulis oleh guru, lalu mengirimkan foto kolase proses memasak dan video presentasi orang tua dan anak tentang cara membuat masakan tersebut setelah masakan tersebut siap disantap. Pada kegiatan ini orang tua tidak mengalami kesulitan yang berarti karena mereka sudah terbiasa membaca resep masakan. Kesulitan ditemui 
saat mereka harus presentasi karena grogi, dan susah memilih dan menyusun kata yang ingin disampaikan. Mereka harus berlatih berkalikali atau melakukan video editing agar video yang dikirim sesuai harapan.

\section{Informational}

Tingkat literasi informational adalah tingkat di mana seseorang diharapkan mampu mengakses pengetahuan dengan bahasa. Kecakapan literasi orang tua pada tingkat ini diasah dengan cara Komunitas Literasi Wadas Kelir dan guru MI Al Falah UM Jakarta Timur mengirimkan tautan pembelajaran yang berkaitan dengan materi yang sedang dipelajari. Orang tua diminta untuk membimbing anak memperkaya cakupan materi dari berbagai sumber, baik buku, majalah, koran maupun internet, kemudian merangkumnya ke dalam sebuah tulisan. Kegiatan ini tidak terlalu sulit bagi orang tua karena mereka cukup terbiasa mengakses informasi dari internet. Berdasarkan hasil wawancara, internet adalah pilihan utama mencari informasi. Namun sayangnya, hanya sebagian kecil orang tua yang memperhatikan kesahihan sumber informasi tersebut.

Dari sinilah para orang tua mendapatkan banyak pengetahuan yang akan dijadikan sebagai bahan untuk menulis. Tidak hanya itu, para orang tua pun mendapatkan wawasan tulisan yang terkait dengan judul, pembuka, isi, dan penutup yang didapatkan dari tulisan informasiyang dibacanya. Dengan kemampuan inilah, maka orang tua oleh Komunitas Literasi Wadas Kelir dan guru MI Al Falah UM Jakarta Timur telah dikondisikan untuk memiliki pengetahuan literasi yang bagus, dan memiliki kemampuan menulis yang sudah siap untuk dipraktikkan.

\section{Epistemic}

Epistemic adalah tingkatan paling tinggi kemampuan literasi di mana seseorang dapat mentransformasikan pengetahuan dalam bahasa. Orang tua telah melalui banyak hal dalam mendampingi anak belajar di rumah selama masa pandemi Covid-19. Berbagai pengalaman dirasakan dalam menghadapi berbagai tantangan yang belum pernah dirasakan bahkan belum pernah terbayangkan sebelumnya agar proses belajar anak tetap berjalan dengan baik meskipun pembelajaran diselenggarakan jarak jauh tanpa tatap muka langsung dengan guru. Disadari atau tidak, orang tua telah memiliki banyak strategi bukan hanya dalam mendampingi anak belajar, tetapi juga dalam menghadapi persoalan lain di rumah. Menata sedemikian rupa agar seluruh kegiatan di dalam rumah berjalan dengan baik selama masa pembatasan sosial diberlakukan dan seluruh kegiatan berpusat di rumah. Disinilah kecakapan epistemic orang tua diasah.

Dari sinilah Komunitas Literasi Wadas Kelir dan guru MI Al Falah UM Jakarta Timur meminta orang tua menuangkan pengalamannya ke dalam tulisan. Orang tua mentransformasikan pengetahuan dalam bentuk pengalaman inspiratif dengan bahasa tulisan. Awalnya kegiatan ini dianggap mustahil oleh para orang tua. Mereka menganggap dirinya tidak mampu, tidak bisa menulis, sudah lama tidak menulis karena terlalu lama berkutat dengan dapur, dan berbagai alasan yang menunjukkan ketidakpercayaan diri. Namun, guru terus meyakinkan, memberikan dorongan, dan bimbingan sampai orang tua pun bersedia menulis. Bahkan beberapa orang tua menulis sangat rinci hingga menghabiskan beberapa halaman. Dari hasil wawancara didapati bahwa kegiatan menulis menjadi kegiatan baru yang menyenangkan, mengingatkan kembali pada masa-masa sekolah, tempat menuangkan segala emosi yang tidak bisa diluapkan, dan menjadikan lebih bersemangat dalam menghadapi masa pandemi karena mereka mempunyai kesempatan untuk berbagi pengalaman yang bermanfaat. 
Pada awal kegiatan, kebanyakan orang tua merasa malu untuk menulis, tulisan yang dihasilkan sangat pendek karena merasa tak punya ide dan terbatasnya kosakata serta sulitnya menyusun kalimat. Tetapi, ketika tulisan orang tua dikumpulkan melalui pesan Whats $A p p$ dan mendapat apresiasi positif dari guru dan sekolah, mereka menjadi bersemangat menulis. Mereka jadi suka membaca untuk memperkaya pengetahuan, kosakata dan memperbaiki struktur kalimat. Lebih dari itu, mereka senang berbagi pengalaman inspiratif.

Serangkaian kegiatan pendampingan orang tua terhadap anak-anaknya selama masa pandemi Covid-19 telah mengasah kemampuan literasi orang tua khususnya wali murid kelas 6 MI Al-Falah UM. Sebuah buku berisi pengalaman orang tua selama mendampingi anak PJJ telah terbit. Kolaborasi literasi antara Komunitas Literasi Wadas Kelir dan guru MI Al Falah UM Jakarta Timur menjadi kata kunci agar pembelajaran jarak jauh tanpa tatap muka secara langsung berjalan dengan baik. Hasil wawancara menunjukkan bahwa awal kegiatan literasi jarak jauh dilaksanakan sangat berat. Bukan hanya masalah materi pelajaran yang harus mereka pelajari kembali, tetapi juga banyak miskomunikasi antarpesan yang dikirimkan. Meskipun mereka sudah memahami informasi yang disampaikan, mereka sering kali mengkonfirmasi ulang pada guru untuk meyakinkan karena takut apa yang diterimanya tidak sama dengan pesan yang dimaksud. Seringkali Komunitas Literasi Wadas Kelir dan guru MI Al Falah UM Jakarta Timur pun kurang memahami pertanyaan orang tua karena mereka mengaku kesulitan menyusun kalimat efektif yang mudah dipahami. Namun, seiring kegiatan pendampingan yang mereka lalui, kemapuan literasi mereka mengalami peningkatan. Optimalisasi literasi dapat menjadi salah satu upaya untuk meningkatkan keterampilan komunikasi sekaligus keterampilan menulis.
Orang tua, guru, dan Komuitas Literasi Wadas Kelir semakin mudah dalam melakukan kegiatan jarak jauh karena transformasi pengetahuan dan keterampilan literasi bisa berjalan dengan baik.

\section{PENUTUP}

Komunikasi menjadi kunci keberlangsungan pembelajaran jarak jauh di masa pandemi Covid-19. Kemampuan komunikasi bisa meningkat seiring meningkatnya kemampuan literasi. Kerja sama dalam bidang literasi antara sekolah dengan komunitas literasi menjadi hal penting dalam upaya meningkatkan literasi orang tua. Melalui kualitas literasi yang baik, maka orang tua dapat memperluas dan mengakses ilmu pengetahuan serta infromasi dari berbagai sumber secara tepat yang akan mendukung proses belajar di rumah, dan literasi menulis juga bisa menjadi terapi kesehatan selama pandemi. Untuk itulah kolaborasi kegiatan literasi yang dilakukan Komunitas Literasi Wadas Kelir dan guru MI Al Falah UM Jakarta Timur dengan model daring menunjukkan hal penting yang dikembangkan.

Model kegiatan peningkatan literasi untuk orang tua wali murid ini dikembangkan dalam empat kegiatan literasi menulis yang menarik. Pertama, performative, yang dilakukan melalui pengkondisikan kegiatan membaca dan menulis menggunakan bahasa yang dilakukan oleh orang tua. Di sini Komunitas Literasi Wadas Kelir dan guru MI Al Falah UM Jakarta Timur melakukan penyediaan bacaan secara online, mendampingi kegiatan membaca, sampai menjadi mitra konsultasi para orang tua. Kedua, functional, yang dilakukan dengan mengkondisikan orang tua untuk terbiasa menggunakan bahasa tulis untuk mengekspresikan kegiatan sehari-harinya. Ketiga, informational, memberikan keterampilan pada orang tua untuk bisa mengangkes pengetahuan dari berbagai sumber dengan bahasa dan memberikan teknik- 
teknik cara membaca yang baik agar memahami benar konsep ilmu pengetahuan yang disajikan. Keempat, epistemic, memberikan keterampilan dalam mentransformasi pengetahuan dalam tulisan sehingga orang tua bisa menulis dengan baik.

Dengan mengajak dan memberikan pendampingan pada orang tua dalam empat kegiatan literasi ini, literasi orang tua mengalami peningkatan.

Membukukan hasil tulisan orang tua dapat menjadi bentuk apresiasi yang dapat meningkatkan motivasi orang tua untuk terus meningkatkan literasi dan keterampilan komunikasi yang sangat dibutuhkan selama mendampingi anak belajar di rumah pada masa pandemi Covid-19.

\section{DAFTAR PUSTAKA}

Azmi, N. (2020). Manfaat Menulis Jurnal untuk Kesehatan Mental Anda. Retrieved October 27, 2020, from https://hellosehat.com/hidupsehat/psikologi/manfaat-menulis-jurnalmental/\#gref

Cahyati, N., \& Kusumah, R. (2020). Peran Orang Tua Dalam Menerapkan Pembelajaran Di Rumah Saat Pandemi Covid 19. Jurnal Golden Age, 4(1), 152-159.

Indopositive. (2016). 5 Manfaat Psikologis Saat Kita Menulis Jurnal Pribadi.

Kemdikbud. (2020). Kemdikbud Terbitkan Pedoman Penyelenggaraan Belajar dari Rumah.

Kurniati, E., Nur Alfaeni, D. K., \& Andriani, F. (2020). Analisis Peran Orang Tua dalam Mendampingi Anak di Masa Pandemi Covid-19. Jurnal Obsesi : Jurnal Pendidikan Anak Usia Dini, 5(1), 241. https://doi.org/10.31004/obsesi.v5i1.541

Munir. (2009).KOMINUKASI@ 2009, Penerbit Alfabeta , Bandung Penulis Tahun Penerbit ISBN: Munir.

Padmadewi, N. N., Artini, L.P., Nitiasih, P. K., \& Suandana, I. W. (2018). Memberdayakan keterlibatan orang tua dalam pembelajaran literasi di sekolah dasar. Ilmu Sosial Dan Humaniora, 7(1), 64-76.
Pancarrani, B., Amroh, I. W., \& Noorfitriana, Y. (2017). Peran Literasi Orang Tua Dalam Perkembangan Anak. BIBLIOTIKA: Jurnal Kajian Perpustakaan Dan Informasi, 1(2), 23-27. https://doi. org/10.17977/um008v1i22017p023

Raco, J. . (2010). Metode Kualitatif: Jenis, Karakteristik dan Keunggulannya. Jakarta: Grasindo.

Rahman, Sopandi, W. S., Widya, R. N., \& Yugafiati, R. (2017). Literasi dalam Konteks Keterampilan KomunikasiAbad21 padaMahasiswaPendidikan Guru Sekolah Dasar. 14(1), 55-64. Retrieved from file:///C:/Users/user/Downloads/BEDAH BUKU ONLINE/LITERASI DALAM KONTEKS KETERAMPILAN KOMUNIKASI ABAD 21.pdf

Simanjuntak, R. A. (2020). Dikeluhkan Orang Tua, Segera Evaluasi Pembelajaran Jarak Jauh. Retrieved October 27, 2020, from https:// edukasi.sindonews.com/read/113822/144/ dikeluhkan-orang-tua-segera-evaluasipembelajaran-jarak-jauh-1595750876

Sindonews. (2020). Siswa Depresi karena PJJ Berujung Maut, KPAl: Kita Ingin Periksa... Retrieved October 27, 2020, from https://edukasi. sindonews.com/read/205284/212/siswadepresi-karena-pjj-berujung-maut-kpai-kitaingin-periksa-gurunya-1603379429

Subandi. (2011). Qualitative Description as one Method in Performing Arts Study. Harmonia, (19), 173-179.

Suranny, L. E., Kidul, D. N., \& Ngadirojo, K. (2018). Peran orang tua untuk menumbuhkan budaya literasi dalam keluarga the role of parents to grow the literation culture in the family. Jurnal JARLITBANG Pendidikan, 4(2), 549-555.

Wardhani, T. Z. Y., \& Krisnani, H. (2020). Optimalisasi Peran Pengawasan Orang Tua Dalam Pelaksanaan Sekolah Online Di Masa Pandemi Covid-19. Retrieved October 27, 2020, from http://jurnal.unpad.ac.id/prosiding/article/ view/28256/pdf 